www.czasopisma.marszalek.com.pl/pl/10-15804/npw

\author{
PrzemYStaW SIERADZAN \\ Uniwersytet Gdański \\ ORCID: https://orcid.org/0000-0002-9255-7417
}

\title{
Reformy społeczno-polityczne w Uzbekistanie w czasie prezydentury Szawkata Mirzijojewa
}

\section{Socio-political Reforms in Uzbekistan during the Presidency of Shavkat Mirziyoyev}

\section{Abstract}

The paper aims to present various aspects of the reform process initiated and implemented by Shavkhat Mirziyoyev, the president of the Republic of Uzbekistan, since 2016. The main subjects of consideration are vectors of political change in the spheres of institutions of political power, economy and foreign policy in the broader context of the legacy of the first president Islam Karimov's reign and the heritage of the Soviet period. The fundamental reforms have embraced democratization of political system, fight against corruption, extension of civil rights and abandoning of isolationism in international relations, and are sometimes decribed as the „Uzbek Thaw”. However they seem to be very meaningful, one will be able to evaluate their significance for the statehood of the independent Uzbekistan only from the perspective of future decades.

Keywords: Uzbekistan, Central Asia, reforms, liberalization, transformation, clanishness, corruption, isolationism, geopolitics 


\title{
Социально-политические реформы в Узбекистане в период президентства Шавката Мирзиёева
}

\section{Аннотация}

В данной статье представлены различные аспекты процесса реформ, которые были инициированы и осуществлялись президентом Республики Узбекистан Шавхатом Мирзиёевым с 2016 года. Были рассмотрены такие вопросы, как векторы политических изменений в сфере институтов политической власти, экономики и внешней политики в широком контексте наследия правления первого президента Ислама Каримова и советского периода. Фундаментальные реформы в стране были направлены на демократизацию политической системы, борьбу с коррупцией, расширение гражданских прав и отказ от изоляционизма в международных отношениях, что иногда называют «узбекской оттепелью». Как бы они ни казались значимыми, оценить их значение для государственности независимого Узбекистана можно будет только с перспективы будущих десятилетий.

Ключевые слова: Узбекистан, Центральная Азия, реформы, либерализация, трансформация, клановость, коррупция, изоляционизм, геополитика

\section{Uwagi wstępne}

\begin{abstract}
$\mathrm{O}$ d 2016 roku w Uzbekistanie pod przywództwem nowego prezydenta Szawkata Mirzijojewa urzeczywistniany jest kompleksowy program reform, obejmujący sfery struktury polityczno-instytucjonalnej, gospodarki, finansów, sądownictwa, praw obywatelskich oraz stosunków międzynarodowych. Cel niniejszego studium stanowi wieloaspektowa prezentacja, wyjaśnienie i interpretacja procesów reformatorskich zainicjowanych i implementowanych przez nowego przywódcę państwa uzbeckiego. Przedmiotem rozważań są przede wszystkim kierunki przemian politycznych wprowadzanych od 2016 roku w sferze instytucji władzy, gospodarki i polityki zagranicznej w szerszym kontekście spuścizny rządów pierwszego prezydenta niepodległego Uzbekistanu Islama Karimowa oraz dziedzictwa czasów radzieckich. Rozważania i analizy zawarte w niniejszej pracy opierają się na charakterystycznym dla nauk o polityce podejściu interdyscyplinarnym, wyrażającym się w selektywnym czerpaniu $\mathrm{z}$ dorobku, metod i technik różnych dyscyplin i subdyscyplin naukowych, w tym nauk o cywilizacji,
\end{abstract}


historii, geografii, socjologii, ekonomii i antropologii, mającym na celu właściwą konceptualizację zjawisk i procesów politycznych.

Uzbekistan jest państwem podwójnie śródlądowym ${ }^{1}$ położonym w Azji Centralnej. Jego terytorium, którego większa część znajduje się w delcie rzek Syr-daria i Amu-daria, obejmuje 447 tys. $\mathrm{km}^{2}$. We wschodniej i południowo-wschodniej części państwa łączą się dwa wielkie systemy górskie - Tienszan oraz Hisaro-Ałaj. Największe skupiska ludności znajdują się w żyznych kotlinach górskich, takich jak Fergańska, Taszkiencka i Samarkandzka. Około $80 \%$ terytorium kraju zajmują stepy i pustynie, z których najrozleglejsza nosi nazwę Kyzył-kum (Czerwone Piaski). W obecnym kształcie jako niepodległe państwo Uzbekistan istnieje od 1991 roku (Bodio, 2001, s. 22-23).

W minionych wiekach na ziemiach dzisiejszego Uzbekistanu znajdowały się tak prężne geopolityczne ośrodki siły, jak Baktria, Transoksania, Buchara, Chorezm i Chiwa, które zdumiewały ówczesny świat swoją kulturą materialną i duchową, zamożnością i poziomem rozwoju technologicznego. Od XIV do XVI wieku na tym właśnie terytorium znajdowało się centrum Imperium Timurydów, będącego wówczas jedną z największych potęg gospodarczych i militarnych. Wspaniałe zabytki Samarkandy, Buchary, Taszkientu i Chiwy przypominają o latach minionej chwały, zachwycając turystów i badaczy. Przez ziemie dzisiejszego państwa uzbeckiego przebiegała kluczowa część Wielkiego Szlaku Jedwabnego - najważniejszej drogi handlowej w dziejach ludzkości, umożliwiającej wymianę dóbr kultury między odległymi cywilizacjami Azji Wschodniej, Bliskiego Wschodu i Europy. Od XVIII wieku terytoria te, zwane wówczas Turkiestanem Zachodnim, stopniowo spychane były na peryferie globalnego układu sił. Ziemie dzisiejszego Uzbekistanu (na których znajdowały się wówczas trzy niepodległe państwa - Emirat Buchary, Chanat Kokandzki i Chanat Chiwy), podobnie jak i cała Azja Centralna, stały się przedmiotem imperialistycznej rywalizacji Wielkiej Brytanii i Imperium Rosyjskiego o strefy wpływów i hegemonię geopolityczną. Rywalizacja ta przeszła do historii jako „Wielka Gra” (Leontev, 2008; Hopkirk, 2011). Stroną

1 Państwo podwójnie śródlądowe samo nie posiada dostępu do morza oraz graniczy wyłącznie z państwami bez dostępu do morza. W momencie powstawania niniejszego artykułu istnieją tylko dwa takie państwa - Uzbekistan (graniczący ze śródlądowymi Kazachstanem, Kirgistanem, Tadżykistanem, Turkmenistanem i Afganistanem) oraz Liechtenstein (graniczący jedynie ze Szwajcarią i Austrią). 
zwycięską w walce o wpływy w Turkiestanie okazała się Rosja. Po wielu dekadach ekspansji militarnej i politycznej w 1873 roku ziemie Turkiestanu Zachodniego znalazły się pod kontrolą Imperium Rosyjskiego² ${ }^{2}$ zaś w październiku 1924 roku powstała tam Uzbecka Socjalistyczna Republika Radziecka. Do uzyskania niepodległości w 1991 roku Uzbekistan był częścią Związku Socjalistycznych Republik Radzieckich, ściśle powiązaną politycznie i gospodarczo z innymi podmiotami wchodzącymi w skład socjalistycznego supermocarstwa.

Islam Karimow, pierwszy prezydent niepodległego Uzbekistanu, za najważniejszą wartość uznawał stabilność państwa. Hołdował polityce zachowawczej i izolacjonistycznej, która w jego przekonaniu stanowiła najpewniejszą gwarancję zapobieżenia czynnikom wewnętrznym i zewnętrznym, mogącym potencjalnie zagrozić władzy jego otoczenia politycznego. Jego następca i długoletni współpracownik Szawkat Mirzijojew postanowił wprowadzić odważne reformy, które w znacznym stopniu odmieniły życie społeczno-polityczne Uzbekistanu. Gruntowna modernizacja instytucjonalna, gospodarcza, finansowa i prawna, połączona $z$ kampanią antykorupcyjną, rozszerzeniem praw obywatelskich oraz odrzuceniem polityki izolacjonizmu, zyskała publicystyczne miano „Uzbeckiej Odwilży” (Džanašiâ, 2018). Skala przemian ostatnich lat wydaje się tak znacząca, że Tadeusz Bodio, wybitny badacz Azji Centralnej, nazwał Uzbekistan „państwem w totalnej przebudowie" (Bodio, 2020). W istocie wydaje się, że centralnoazjatycka republika wkroczyła w okres głębokiej transformacji państwowości i społeczeństwa.

\section{Dziedzictwo rządów Islama Karimowa}

Choć Islam Karimow bez wątpienia zajmuje istotne miejsce w najnowszych dziejach Uzbekistanu, to dziedzictwo jego rządów budzi znaczne kontrowersje - ma zarówno zdecydowanych obrońców, jak i nieprzejednanych krytyków.

Pierwszy prezydent niepodległego Uzbekistanu urodził się w 1938 roku w Samarkandzie. Karierę polityczną rozpoczął w czasach radzieckich. Islam

2 Do tego czasu Kokand wszedł w skład guberni turkiestańskiej, a Emirat Buchary i Chanat Chiwy uznały hegemonię Petersburga, akceptując status zależności wasalnej. 
Karimow, z wykształcenia inżynier mechanik i ekonomista, od 1966 pełnił różne funkcje w uzbeckim Państwowym Komitecie Planowania.W 1983 roku objął posadę ministra finansów, a trzy lata później wicepremiera Uzbeckiej SRR. W 1989 roku stanął na czele Komitetu Centralnego Komunistycznej Partii Uzbekistanu jako jego I Sekretarz. 24 marca 1990 roku Rada Najwyższa Uzbeckiej SSR wybrała go prezydentem państwa. 31 sierpnia 1991 roku, w dziesięć dni po upadku zamachu stanu Giennadija Janajewa, występując jako głowa republiki i reprezentując jej instytucje, proklamował niepodległość Uzbekistanu, ogłaszając zarazem wystąpienie ze Związku Radzieckiego. Gdy 1 listopada 1991 roku partia komunistyczna w republice przekształciła się w Ludowo-Demokratyczną Partię Uzbekistanu, również stanął na jej czele (Islomkarimov.ru).

29 grudnia 1991 roku Islam Karimow wybrany został prezydentem. W 1995 roku jego kadencja na mocy referendum ludowego przedłużona została do roku 2000. Kolejne reelekcje przywódca uzyskiwał w latach 2000, 2007 i 2015.

Islam Karimow stanął na czele państwa zmagającego się z licznymi trudnościami. Rozpad Związku Radzieckiego przyniósł osłabienie dotychczasowych powiązań handlowych i zerwanie łańcuchów dostaw, co pogrążyło w kryzysie gospodarkę opierającą się dotąd w znacznej mierze na monokulturze uprawy bawełny. Od samego początku musiał zmagać się z ekspansją radykalnego islamu politycznego - ruchy islamistyczne cieszyły się w Uzbekistanie popularnością znacznie większą niż w pozostałych państwach Azji Centralnej - wpływy doktryn fundamentalistycznych były szczególnie rozległe w Kotlinie Fergańskiej, gdzie znaczne poparcie miały organizacje takie jak Islamski Ruch Uzbekistanu oraz międzynarodowe ugrupowanie Hizb-ut-Tahrir (HT), dążące do przekształceniu państwa w teokrację islamską. Za nie mniej istotne źródła zagrożeń dla bezpieczeństwa państwowego Uzbekistanu uznawano sąsiedztwo z niestabilnymi państwami regionu, do których zaliczyć należy Afganistan i Tadżykistan, a także, choć w mniejszym stopniu, Kirgistan (Starr, 2018, s. 20-25).

Islam Karimow motywem przewodnim wstępu swojej programowej pracy Uzbekistan na progu XXI wieku uczynił pytanie: „czy uświadamiamy sobie zagrożenia dla naszej stabilności i bezpieczeństwa? Jak możemy przeciwstawić się tym zagrożeniom, co może być gwarancją stabilnego i trwałego 
rozwoju naszego społeczeństwa oraz zachowania równowagi geopolitycznej w regionie, w którym żyjemy?". Pierwszy rozdział książki Islam Karimow poświęcił zagrożeniom bezpieczeństwa, wśród których wymienił konflikty regionalne, ekstremizm i fundamentalizm religijny, szowinizm wielkomocarstwowy i agresywny nacjonalizm, sprzeczności etniczne i narodowe, korupcję i przestępczość, dziedziczne obsadzanie urzędów i stosunki klanowe oraz problemy ekologiczne (Karimov, 2001, s. 5).

Konsekwencją uznania przez Karimowa stabilności i bezpieczeństwa państwa za priorytet było przyjęcie zachowawczego i autorytarnego kursu w polityce wewnętrznej. Zdecydowane, niekiedy bezwzględne działania represyjne, podejmowane były przede wszystkim przeciwko ruchom i ideologii radykalnego islamizmu, cieszącego się znaczną popularnością przede wszystkim w Kotlinie Fergańskiej (przykładem mogą tu być wydarzenia z 2005 roku, gdy w Andiżanie stłumione zostały rozruchy inspirowane przez islamistów). Ograniczenia w działalności dotykały jednakże wszelką opozycję polityczną, a nie jedynie fundamentalistów religijnych. Bardzo wzrosło znaczenie Służby Bezpieczeństwa Narodowego, która tłumiła wszelkie przejawy buntu i rebelii. Elity polityczne Taszkientu cechował swoisty konserwatyzm - panowało wśród nich przekonanie, że zbyt ambitne reformowanie instytucji, procedur i metod działania odziedziczonych po czasach radzieckich mogłoby doprowadzić do destabilizacji państwa. Rezultatem niechęci do działań reformatorskich było rozpowszechnienie się praktyk korupcyjnych. Nieformalne powiązania i układy, często o charakterze klanowym, w znacznym stopniu determinowały mechanizmy podejmowania decyzji. Pod pojęciem „klanu” należy rozumieć tu nieformalną grupę polityków wspierających się nawzajem, opartą na wspólnej tożsamości, której fundamenty mają charakter rodzinny lub rodowy, terytorialny lub powiązany ze wspólnym doświadczeniem kariery w aparacie biurokratycznym (najczęściej wszystkie te czynniki występują łącznie). Klany stanowią zorganizowane hierarchicznie struktury klientelistyczno-patronackie o wysokim stopniu lojalności i solidarności. Osobliwością uzbeckich podziałów klanowych jest znikoma rola czynnika religijnego i etnicznego (do klanów mogą należeć muzułmanie i ateiści, a także np. Tadżycy, Kirgizi i Tatarzy). Przynależność do klanu i pozycja w jego hierarchii jest ważnym czynnikiem determinującym proces rekrutacji elit politycznych. Zdecydowanie najsilniejsze z nich są trzy: 
taszkiencki, samarkandzko-bucharski i fergański. Mniejszą, choć też istotną rolę odgrywają klany o znaczeniu regionalnym: andiżański i namangański (pozostające w sojuszu z taszkienckim), peryferyjny klan karakałpacki, chorezmijski oraz „Surkasz” (akronimiczna zbitka słowna - sojusz dwóch klanów południowych: kaszkadaryjskiego i surchandaryjskiego). Niekiedy wymienia się także dziewiąty klan dżyzacki (Bazyleva, 2017, s. 77-82).

Petryfikacja systemu politycznego i stagnacja stały się ceną, którą Uzbekistan płacił za zachowawczy kurs prezydenta Karimowa. Z drugiej jednak strony państwo zachowało integralność terytorialną w nadzwyczaj turbulentnym otoczeniu międzynarodowym. O kursie tym wypowiadał się między innymi pierwszy prezydent Kirgistanu Askar Akajew (przebywający obecnie na uchodźstwie), którego zdaniem stworzenie trwałego systemu politycznego gwarantuje Uzbekistanowi stabilność i jest najcenniejszym elementem dziedzictwa Karimowa (Mirzoân, 2016). Trudno zaprzeczyć, że względna trwałość i wewnątrzsterowność uzbeckiej państwowości kontrastuje z permanentnie turbulentnym modelem kirgiskim.

Z zachowawczym kursem w polityce wewnętrznej Uzbekistanu, przyjętym przez Islama Karimowa, kontrastowała również elastyczność Taszkientu w relacjach międzynarodowych. Państwo unikało trwałych sojuszy, hołdując zasadzie wielowektorowości. Uzbekistan zachował podmiotowość i względną niezależność od wielkich mocarstw aktywnych na obszarze Azji Centralnej, przede wszystkim Rosji, Chin i Stanów Zjednoczonych.

Politykę Islama Karimowa cechował także nacjonalizm, wyrażający się w tzw. uzbekizacji kultury narodowej. W sferze symbolicznej prezydent najczęściej odwoływał się do dorobku Imperium Timura oraz Chanatu Buchary. Jednocześnie negatywnie odnosił się do dziedzictwa Imperium Rosyjskiego i Związku Radzieckiego, co zresztą niejednokrotnie zaważyło negatywnie na stosunkach między Taszkientem i Moskwą.

Pierwszy prezydent niepodległego Uzbekistanu zmarł 2 września 2016 roku. Jego śmierć wywołała krótkotrwały kryzys konstytucyjny. Zgodnie z ustawą zasadniczą, tymczasową głową państwa został przewodniczący Senatu Nigmatilla Juldaszew, jednak niemal od razu zrezygnował z najwyższego urzędu w państwie. 


\section{Szawkat Mirzijojew jako inicjator uzbeckich reform}

Szawkat Mirzijojew urodził się w 1957 roku w wilajecie dżyzackim (we wschodniej części państwa, w pobliżu granicy z Tadżykistanem). W 1981 roku ukończył Taszkiencki Instytut Irygacji i Melioracji, następnie został jego pracownikiem naukowym, uzyskując stopnień naukowy kandydata nauk technicznych. W 1990 roku został deputowanym Rady Najwyższej Uzbeckiej SRR i jednocześnie przewodniczącym komisji mandatowej. Po uzyskaniu niepodległości przez państwo wstąpił w szeregi Ludowo-Demokratycznej Partii Uzbekistanu. W latach 1992-1996 stanął na czele administracji dzielnicy Taszkientu Mirzo Ulugbek. W wyborach 1994/1995 roku ponownie uzyskał mandat deputowanego parlamentu (Olij Mażlis).W 1996 roku został gubernatorem rodzinnego wilajetu dżyzackiego, a w 1999 uzyskał parlamentarną reelekcję. W 2001 roku stanął na czele wilajetu samarkandzkiego (Sobolev, 2010). Przełomem w karierze politycznej Szawkata Mirzijojewa stał się rok 2003, gdy polityk ten został wybrany przez Olij Madżlis na premiera rządu Republiki Uzbekistan (Bodio, 2020, s. 74-75). Od tego czasu uzbecki parlament misję tworzenia rządu powierzał mu jeszcze trzykrotnie - w 2005, 2010 i 2015 roku. Funkcję szefa rządu Szawkat Mirzijojew pełnił do 2016 roku. W tym okresie był najbliższym współpracownikiem oraz lojalistą prezydenta Karimowa, którego politykę realizował stojąc na czele gabinetu ministrów (Biznes Rossii, 2018). W tym okresie stopniowo wzmacniał swoją pozycję polityczną, stając się drugim najbardziej wpływowym politykiem państwa. W tym okresie miał reputację raczej kompetentnego i profesjonalnego wykonawcy woli politycznej prezydenta niż samodzielnego polityka i potencjalnego lidera. Co więcej, miał początkowo reputację polityka mało wyrafinowanego w metodach i niekiedy brutalnego, skłonnego do rozwiązań siłowych, której zaprzeczyła jego późniejsza kariera. Jako szef rządu nadzorował liczne projekty, wśród których najistotniejsze były: strategia na rzecz poprawy standardów życia ludności, program działań na rzecz poprawy warunków pracy i przestrzegania praw pracowniczych, pakiet inicjatyw na rzecz poprawy sytuacji ekologicznej wokół (częściowo wyschniętego) Jeziora Aralskiego, kampania na rzecz modernizacji rolnictwa oraz program kredytowania mikroinwestycji (Starr, 2018, s. 32-33). 
Po śmierci Islama Karimowa i rezygnacji przewodniczącego Senatu Nigmatilly Juldoszewa obie izby Olij Mażlis powierzyły 8 sierpnia 2016 roku Szawkatowi Mirzijojewowi stanowisko tymczasowej głowy państwa. Decyzja parlamentu zaskoczyła wielu obserwatorów, ponieważ premier nie był dotąd uważany za faworyta do roli następcy Karimowa. Uchwała wzbudziła pewne kontrowersje natury prawnej, ponieważ podobna sytuacja nie została przewidziana przez ustawę zasadniczą, jednak większość uzbeckich konstytucjonalistów, między innymi także najwybitniejszy z nich Akmal Saidow, uznała procedurę za prawomocną (Kun.uz, 2016).

4 grudnia 2016 roku Szawkat Mirzijojew odniósł zwycięstwo na wyborach prezydenckich, uzyskując 88,61\% głosów, a 14 grudnia 2016 roku został zaprzysiężony na urząd prezydenta. Moment ten stanowił kamień milowy w dziejach centralnoazjatyckiego państwa. Autorytet dotychczasowego przywódcy bez wątpienia był czynnikiem stabilizującym system polityczny Uzbekistanu. Mimo to tranzycja władzy dokonała się pokojowo, a państwo uniknęło niepokojów i chaosu. Dotychczasowy przebieg jego kariery mógł wskazywać na to, że nowy prezydent będzie kontynuatorem dotychczasowego kursu, stawiając przy tym tezę o jego sojuszu z dotychczasowymi elitami służb specjalnych (Bazyleva, 2017, s. 77-82). Rozwój wydarzeń okazał się jednak nadzwyczaj zaskakujący.

Szawkat Mirzijojew stanął przed niełatwym dylematem: mógł kontynuować dotychczasowy kurs, albo też zainicjować program transformacji państwa. Choć prezydent należał do ścisłego grona najbliższych współpracowników wieloletniego przywódcy państwa Islama Karimowa, to zachowując szacunek dla dokonań poprzednika, postanowił zrealizować wyraźną korektę implementowanego modelu transformacji. Relatywnie szybko zdobył osobisty autorytet, niezbędny dla prowadzenia polityki głębokich reform. Jako przywódca polityczny, zarówno w oczach Uzbeków, jak i międzynarodowych obserwatorów, zyskał reputację polityka ambitnego i nie obawiającego się podejmować odważnych decyzji. Okres prezydentury Szawkata Mirzijojewa przyniósł liberalizację systemu politycznego Uzbekistanu, niekiedy określaną mianem „odwilży” (Žegulev, 2018).

Tadeusz Bodio w analizie stylu przywództwa prezydenta Szawkata Mirzijojewa zwraca uwagę na częste odwoływanie się przez niego do emocji patriotycznych, determinację we wprowadzaniu reform, odwagę, a także 
gotowość do podejmowania ryzyka. Nowy uzbecki lider ceni innowacje w zarządzaniu państwem, a także umiejętnie mobilizuje swoich współpracowników. Nie szczędzi gorzkich słów urzędnikom państwowym za ich błędy i uchybienia, niedociągnięcia w sprawowaniu władzy, ale także potrafi wykazać postawę samokrytyczną. Jego styl przywództwa łączy elementy autokratyczne i demokratyczne (Bodio, 2020, s. 106).

Prezydent Uzbekistanu zyskał obiegowe miano „uzbeckiego Deng Xiaopinga” (Paderina, 2018). Choć zasadność porównania prezydenta do architekta chińskich reform i twórcy strategii otwarcia na świat będzie można ocenić najwcześniej z perspektywy kilku dekad, nie ulega wątpliwości, że pierwsze lata sprawowania przez niego władzy były bardzo znaczącym przełomem dla Uzbekistanu.

\section{Demokratyzacja modelu państwa}

Charakterystycznym atrybutem polityki Szawkata Mirzijojewa jest odejście od wcześniej realizowanego autorytarnego modelu transformacji państwa. Nowy prezydent w początkowym okresie sprawowania władzy postępował bardzo ostrożnie. Doceniał dokonania I. Karimowa, zainicjował budowę jego pomnika i powstanie naukowo-edukacyjnego kompleksu jego imienia (Islomkarimov.uz b). Wraz z umocnieniem swojej pozycji zaczął stopniowo odchodzić od uprzedniego kursu politycznego - „twardego autorytaryzmu”, w imię zapobiegania destabilizacji istniejącego systemu, którego trwanie we względnie niezmiennej formie postrzegano jako najwyższą wartość. Powodzenie programu reform uzależnione było od wielu czynników, wśród których można wymienić m.in. umocnienie autorytetu prezydenta i jego pozycji w systemie władzy, pozyskanie przez przywódcę sojuszników w kraju i za granicą oraz uniezależnienie się od Służby Bezpieczeństwa Narodowego.

Pierwszym zwiastunem zmian kursu politycznego państwa pod nowym przywództwem było przemówienie wygłoszone niemal od razu po wyborze na najwyższy urząd w państwie podczas uroczystej gali z okazji 24. rocznicy uchwalenia konstytucji państwowej. Mirzijojew poddał najwyższych urzędników państwowych druzgocącej krytyce za brak dialogu ze społeczeństwem. Wkrótce po tym wystąpieniu wcielony został projekt prezydenckiej 
„wirtualnej izby przyjęć”. Jest to strona internetowa w języku uzbeckim i rosyjskim, na adres której obywatele mogą wysyłać swoje postulaty, zadawać pytania, zgłaszać wnioski, skarżyć się na problemy i bolączki. Na wszystkie listy (nie będące anonimami i nie naruszające prawa) odpowiadają urzędnicy kompetentni w zakresie poruszanego problemu (Virtual'naâ priemnâ̂ Prezidenta Respubliki Uzbekistan). Uruchomienie „wirtualnej izby przyjęć” zapowiadało rozpoczęcie przez nową elitę władzy wieloaspektowego dialogu ze społeczeństwem.

Już 7 lutego 2017 roku prezydent wydał dekret, w którym zapowiedział pięć najistotniejszych kierunków swojej polityki na lata 2017-2021. Było to: doskonalenie budowania państwa i społeczeństwa; zaprowadzenie praworządności i reforma systemu sądownictwa i prawa; rozwój i liberalizacja gospodarki; rozwój sfery społecznej; zapewnienie bezpieczeństwa, harmonii międzyetnicznej i tolerancji religijnej, oraz implementacja przemyślanej, korzystnej dla wszystkich zainteresowanych stron i pragmatycznej polityki zagranicznej.

Szawkat Mirzijojew po przejęciu władzy szybko uświadomił sobie, że przeprowadzenie głębokich reform nie będzie możliwe bez konfrontacji z wpływowymi funkcjonariuszami Służby Bezpieczeństwa Narodowego beneficjentami dotychczasowego ładu. Mimo to, nowy prezydent zdecydował się rozpocząć konflikt z potężną strukturą. Rozpoczął proces wymiany kadr w służbach specjalnych - zwolnień potencjalnie niesprzyjających mu funkcjonariuszy i zastępowania ich własnymi lojalistami.

31 stycznia 2018 roku odsunięty od dotychczasowej roli został najpotężniejszy i najbardziej wpływowy rywal nowego prezydenta - dotychczasowy przewodniczący Służby Bezpieczeństwa Narodowego, generał-pułkownik Rustam Inojatow, który sprawował ten urząd od 1995 roku. Oficer ten wcześniej nazywany był niekiedy przez publicystów „demiurgiem uzbeckiej polityki”, co było aluzją do jego rozległych wpływów. Przed śmiercią Karimowa spekulowano, że to właśnie Inojatow może stanąć na czele państwa lub mieć istotny wpływ na wyznaczenie następcy (Pannier, 2016). Po odsunięciu od szefowania służbom specjalnym został przeniesiony na nieporównywalnie niższe stanowisko prezydenckiego doradcy. Zastępcy tego potężnego do niedawna polityka skazani zostali na kary długoletniego więzienia. W rezultacie ograniczenia uprawnień Służby Bezpieczeństwa Wewnętrznego część 
z nich przejęło Ministerstwo Spraw Wewnętrznych (na przykład nadzór nad wojskami wewnętrznymi). Emblematyczny charakter miało przemianowanie tej instytucji na Służbę Bezpieczeństwa Państwowego. Równie znaczącym symbolem liberalizacji kursu nowej elity państwa było zburzenie więzienia w Taszkencie, w którym kary więzienia odbywali przeciwnicy polityczni władzy, a także zamknięcie obozu odosobnienia Żasłyk w Karakałpakstanie (The Economist, 2019).

Od pierwszych dni prezydentury Szawkat Mirzijojew deklarował dążenie do znaczącej poprawy sytuacji w sferze przestrzegania praw człowieka i obywatela. Wyrazem tego dążenia było zaproszenie do Taszkientu Wysokiego Komisarza Narodów Zjednoczonych ds. Praw Człowieka Zeida Ra’ada Al-Husseina, które ten przyjął w maju 2017 (co miało, warto nadmienić, jedynie znaczenie symboliczne). Wysoki urzędnik odnotował istotne korzystne zmiany w tej dziedzinie. Miesiąc później uzbecką stolicę odwiedził Sekretarz Generalny ONZ Antonio Guterres, którego spotkanie z prezydentem dotyczyło koordynacji działań na rzecz praw człowieka, bezpieczeństwa regionalnego i zrównoważonego rozwoju (Bowyer, 2018, s. 64).

Za sprawą amnestii i prezydenckich ułaskawień więzienie opuściło 50 osób, którym międzynarodowe organizacje obrony praw człowieka przyznały status więźniów politycznych, między innymi najdłużej więzieni na świecie dziennikarze - Jusuf Ruzimuradow i Muhammad Bekżanow (spędzili w zakładzie karnym odpowiednio 19 i 18 lat), a także wiceprzewodniczący parlamentu pierwszej kadencji po odzyskaniu niepodległości Samandar Kukanow. Wyraźną poprawę sytuacji w sferze przestrzegania praw człowieka i złagodzenie represji politycznych odnotowała, choć nie bez zastrzeżeń, międzynarodowa organizacja Human Rights Watch (Swerdlow, 2019).

Kampania antykorupcyjna i równoległa czystka potencjalnie nielojalnych urzędników objęła nie tylko służby specjalne, ale także inne instytucje związane z resortami siłowymi i władzą sądowniczą. Masowe zwolnienia przeprowadzono w prokuraturze (prezydent Szawkat Mirzijojew w publicznym wystąpieniu nazwał prokuratorów „największymi złodziejami”) (Radio Ozodlik, 2017). Niektórzy skorumpowani oficerowie i urzędnicy zostali skazani na kary wieloletniego więzienia (najgłośniejsza była tu sprawa wieloletniego prokuratora generalnego Raszyda Kadyrowa, skazanego za 10 lat pozbawienia wolności) (Tolibov, 2018). Wymiana kadr objęła także sądownictwo, 
urzędy skarbowe i samorząd terytorialny. Dotychczasowi dygnitarze zostali zastąpieni przez urzędników sprzyjających nowemu prezydentowi. Ci rywale Szawkata Mirzijojewa, którym nie sposób było udowodnić żadnych przestępstw i nadużyć, jak wieloletni minister finansów i wicepremier Rustam Azimow, powiązany z klanem taszkienckim, przeniesieni zostali na znacznie niższe stanowiska (Marszewski, 2018).

Warto odnotować rozszerzenie zakresu praw obywatelskich w Uzbekistanie. Zaprzestano stosowania tortur w celu wymuszania zeznań na oskarżonych. Procesy sądowe stały się znacznie bardziej przejrzyste. W okresie prezydentury Mirzijojewa złagodzona została polityka wobec grup potencjalnie niechętnych władzy, w tym głęboko religijnych muzułmanów. Przeprowadzono serię amnestii, podczas których uwolniono z więzienia licznych więźniów, w tym politycznych. Część ułaskawień odbyła się z okazji świąt religijnych, co w czasie prezydentury Karimowa, gorącego orędownika świeckości państwa, byłoby trudne do wyobrażenia (Muslim.uz, 2018,). Nowe elity władzy nawiązały dialog z muzułmańskim duchowieństwem, wcześniej postrzeganym jako niepewny politycznie rozsadnik nastrojów antyrządowych. Zniesione zostały także zakazy i ograniczenia dotyczące publicznego manifestowania religijności.

Istotnym aspektem reform jest zmiana polityki wobec mieszkańców Kotliny Fergańskiej. Wcześniej postrzegano region jako zdominowany przez fundamentalizm islamski, będący groźnym wewnętrznym ośrodkiem destabilizacji. Po wprowadzeniu nowego kursu politycznego mieszkańcom Fergany umożliwiono korzystanie z pełni praw publicznych, obejmujących także możliwość kariery w administracji publicznej. Rozszerzono zakres wolności słowa, między innymi zmniejszając poziom cenzury treści w Internecie (zniesiono między innymi blokady stron internetowych propagujących treści opozycyjne). W rezultacie nowego kursu politycznego, mającego na celu integrację różnych regionów państwa, wyraźnie spadła rola czynnika klanowego w polityce uzbeckiej (Trofimov, 2017).

Zapowiedź demokratyzacji systemu politycznego zyskała powszechne poparcie i uznanie wśród obywateli. Badania opinii publicznej przeprowadzone w drugiej połowie grudnia 2019 roku wykazują, że aż 96,3\% respondentów popiera strategię reform zainicjowaną i wdrażaną przez Szawkata Mirzijojewa. Choć niebotyczny wskaźnik aprobaty polityki prezydenta przez 
społeczeństwo może zdumiewać, eksperci są zgodni co do tego, że nowy przywódca rzeczywiście zjednał sobie poparcie Uzbeków. Reformy zyskały także uznanie ośrodków eksperckich (Centrum „StrategEast”, Stowarzyszenie dziennikarzy Azji, Rada Współpracy Języków Tureckich) i prasy międzynarodowej („The Economist”) (Bodio, 2020, s. 74).

\section{Reformy gospodarki i finansów państwa}

Uzbekistan jest państwem o liczącym się potencjale gospodarczym. Istnieje fałszywa, choć rozpowszechniona opinia, że gospodarka centralnoazjatyckiego kraju ma charakter monokulturowy i opiera się w przeważającej części na uprawie bawełny.W rzeczywistości niemal jedna trzecia gospodarki przypada na przemysł. Każdego roku wydobywa się tam znaczne ilości gazu ziemnego, ropy naftowej i węgla. Ważną dziedziną gospodarki jest wydobycie i hutnictwo metali kolorowych, takich jak między innymi miedź, cynk, molibden i wolfram, a także wydobycie metali szlachetnych - złota srebra i platyny. Istotnymi gałęziami gospodarki są przemysł chemiczny i tekstylny (Hodžaev, 2019).

Pierwsze trzy lata niepodległości Uzbekistanu przyniosły załamanie finansów państwa i wyraźne obniżenie poziomu życia ludności. Choć od 1995 roku uzbecka gospodarka rozwijała się dynamicznie, to tempo wzrostu gospodarczego ograniczane było przez korupcję polityczną, ograniczenia administracyjne blokujące konkurencję, monopole państwowe oraz brak woli politycznej reformowania systemu fiskalnego państwa. Elity polityczne skupione wokół Islama Karimowa prowadziły politykę, której celem było zakonserwowanie dominującej roli państwa w gospodarce. Paradoksalnie, pomimo preferencji władz dla centralistycznego modelu etatystycznego, w oficjalnych wypowiedziach i tekstach programowych głoszono wyższość neoliberalnego kapitalizmu nad socjalizmem. Prezydent pisał:

Przy tym należy stanowczo odciąć się od skompromitowanych zasad nakazowo-rozdzielczego rządzenia, zdeprawowanego, scentralizowanego systemu, ukształtowanej psychologii „wyrównawczej” i liczenia na innych (...) Klasa średnich właścicieli kształtuje się poprzez stworzenie niejednorodnej gospodarki, zarówno dzięki prywatyzacji i reprywatyzacji, jak i poprzez stymulowanie rozwoju małej 
i prywatnej przedsiębiorczości, czy utworzenie rynku papierów wartościowych (Karimow 2001, 121-122).

Dodatnią stroną modelu gospodarczego wcielanego w życie przez Karimowa był niski poziom zadłużenia wewnętrznego i zagranicznego oraz zapobieżenie wykształceniu się warstwy oligarchów - magnatów finansowych, dysponujących znacznymi aktywami przemysłowymi i finansowymi, które umożliwiają im wywieranie nacisków na instytucje polityczne. W czasach rządów pierwszego prezydenta Uzbekistanu urzędnicy państwowi i ich krewni kontrolowali życie gospodarcze państwa, udaremniając koncentrację kapitału w rękach niezależnych podmiotów (Sattarov, 2017). Niski poziom długu państwowego oraz niewykształcenie się modelu oligarchicznego ułatwił drugiemu prezydentowi Uzbekistanu przeprowadzenie programu gruntownych reform.

Reformy ekonomiczne i finansowe przeprowadzone przez Szawkata Mirzijojewa umożliwiły uzbeckiej gospodarce wkroczenie na ścieżkę rozwoju wyraźnie szybszego, niż dotąd. Jedną z pierwszych przełomowych decyzji gospodarczych nowego prezydenta było uwolnienie suma - uzbeckiej jednostki monetarnej - poprzez legalizację swobodnych transakcji na rynku walutowym. Ekonomiści współpracujący z głową państwa stworzyli strategię przejścia ku swobodnej konwersji uzbeckiej waluty. We wrześniu 2017 roku zniesiono wszelkie ograniczenia dotyczące możliwości zakupu dewiz przez osoby fizyczne i prawne. Dwukrotnie obniżona została kwota obowiązkowej sprzedaży państwu zysków dewizowych. W rezultacie programu dokonało się stopniowe obniżenie kursu waluty narodowej w stronę jej wartości rynkowej. W rezultacie reformy dokonała się deprecjacja suma. Uzbecka waluta straciła ponad połowę swej wartości. Negatywną stroną zjawiska był spadek wartości nabywczej suma i utrata wartości części oszczędności obywateli, pozytywny aspekt sytuacji stanowiła zaś poprawa sytuacji eksporterów. W 2019 roku sum stał się walutą w pełni wymienialną.

Głębokie reformy objęły sferę rolnictwa, przede wszystkim uprawy bawełny i pszenicy. System oparty w znaczącej mierze na hegemonii własności państwowej jest stopniowo zastępowany przez mechanizmy współpracy publiczno-prywatnej (klastry rolno-przemysłowe, funkcjonujące na zasadach rynkowych). 
Nowy przywódca zapowiedział i zaczął wprowadzać reformę przedsiębiorstw państwowych, obejmującą restrukturyzację i przeprofilowanie zakładów nieprzynoszących zysków. Równolegle zaczęto wprowadzać program ułatwień dla przedsiębiorstw prywatnych, wyrażający się między innymi w ograniczeniu przeszkód natury administracyjnej. Zainicjowany został program stymulacji eksportu uzbeckiej produkcji przemysłowej. Zniesiono obowiązujący wcześniej państwowy monopol na eksport produktów rolnych. Wdrożono efektywną strategię aktywnego wsparcia przemysłu maszynowego i motoryzacyjnego, wcześniej pogrążonych w głębokim kryzysie (Biznes Rossii, 2018).

Władze państwa podjęły działania na rzecz wsparcia turystyki. Uzbekistan jest niezwykle pięknym krajem, pełnym fascynujących krajobrazów i zabytków pamiętających czasy największej świetności Szlaku Jedwabnego i potęgi Imperium Tamerlana. Reformy prawa wizowego oraz wsparcie odpowiedniej infrastruktury umożliwiły rozwój ogromnego potencjału turystyki jako gałęzi gospodarki narodowej. Dzięki reformom, w 2018 roku liczba turystów odwiedzających Uzbekistan wyniosła około 5,3 miliony, ponad dwukrotnie więcej niż rok wcześniej (Hodžaev, 2019).

Wśród wdrożonych reform finansowych szczególne znaczenie miały zmiany, które dokonały się w dziedzinie systemu podatkowego. Przeprowadzono reorganizację organów skarbowych, co stało się pretekstem do masowych zwolnień skorumpowanych urzędników. Inne istotne zmiany dotyczyły uproszczenia systemu fiskalnego, wyeliminowania podwójnego opodatkowania oraz wprowadzenia tzw. „wakacji podatkowych” dla spółek i przedsiębiorców (Biznes Rossii, 2018).

Istotnym problemem hamującym rozwój gospodarczy, w znacznym stopniu rozwiązanym przez Szawkata Mirzijojewa, była korupcjogenna kuratela Służby Bezpieczeństwa Narodowego nad prywatnymi przedsiębiorstwami, których właściciele zmuszeni byli odprowadzać część swoich dochodów na rzecz protektorów z tych służb. Co więcej, organy bezpieczeństwa kontrolowały przepływy finansowe z zagranicy.

W rezultacie działań reformatorskich tempo rozwoju gospodarki Uzbekistanu uległo znacznemu przyspieszeniu. Zgodnie z danymi Międzynarodowego Funduszu Walutowego w 2019 roku PKB Uzbekistanu wzrosło o 6.0\%. Zgodnie z prognozami ekonomistów, tempo wzrostu gospodarczego tego 
państwa prawdopodobnie znacznie spowolni w kolejnych latach wskutek kryzysu gospodarki światowej wywołanego przez pandemię COVID-19 i wyniesie około 1,5\% (IMF, s. 5). Warto jednak odnotować, że w opisywanym okresie Uzbekistan zanotuje prawdopodobnie wzrost, podczas gdy część rozwiniętych gospodarek świata pogrąży się w recesji.

Jak zauważa Tadeusz Bodio, realizowana od 2017 roku strategia rozwojowa opiera się na reformach strukturalnych wcielanych w życie przy zachowaniu stabilności makroekonomicznej i wysokiego tempa rozwoju, zakładających ograniczenie monopolistycznej pozycji państwa w gospodarce i wdrażanie mechanizmów rynkowych. Reformy te obejmują zarówno ustawodawstwo, jak i sferę instytucjonalną, finansową oraz rynek, system zarządzania, stymulowanie przedsiębiorczości i walkę z „szarą sferą”. Szczególnie istotnym celem, jaki Szawkat Mirzijojew postawił przed uzbeckimi urzędnikami, przedsiębiorcami i przemysłowcami, jest odejście od eksportu surowców i półproduktów na rzecz wyrobów gotowych o wysokiej wartości dodanej (Bodio, 2020, s. 90).

\section{Zmiana kierunków w polityce zagranicznej państwa}

Kurs polityki zagranicznej Uzbekistanu w okresie prezydentury Islama Karimowa oparty był na zasadach ograniczonej współpracy z partnerami zewnętrznymi, także z państwami sąsiednimi, postrzeganymi jako źródło potencjalnej destabilizacji (dotyczyło to zarówno obcych rządów, jak i uzbeckiej diaspory). Realizowana do 2016 roku strategia izolacjonizmu doprowadziła do znaczącego pogorszenia relacji Taszkientu z innymi państwami regionu.

Mirzijojew zdecydował się na wyraźną korektę tego kursu, która znalazła swój wyraz w polityce otwarcia państwa w zakresie stosunków międzynarodowych. Pierwszym etapem ambitnej strategii było ocieplenie relacji z sąsiadami. Prezydent w swoich wystąpieniach wielokrotnie podkreślał, że rozwój dobrosąsiedzkich stosunków z państwami Azji Centralnej jest jego priorytetem (Sputnik.Ru, 2017). Pierwszymi państwami, które odwiedził nowy prezydent, były Turkmenistan (6-7 marca 2017) i Kazachstan (22 marca). Wykonał też przyjazne gesty wobec mniejszych państw regionu Kirgistanu i Tadżykistanu. Umożliwiło to unormowanie relacji z tymi krajami, zamieszkiwanymi przez liczną uzbecką diasporę. Nowemu przywódcy 
bardzo szybko udało się osiągnąć wymierne sukcesy: dokonano delimitacji i demarkacji spornej granicy z Kirgistanem (co nie udawało się przez 26 lat); podpisano trójstronny traktat o styku granic trzech państw: Uzbekistanu, Turkmenistanu i Kazachstanu; po 25 latach wznowiono połączenie lotnicze na trasie Taszkient-Duszanbe; osiągnięto kompromis w sprawie spornej zapory elektrowni wodnej na rzece Syr-daria, będącej przez lata kością niezgody między Uzbekistanem i Tadżykistanem. Szawkat Mirzijojew zainicjował także podpisanie licznych umów o partnerstwie gospodarczym i politycznym z Kazachstanem, obejmujących między innymi budowę kolei wysokich prędkości, łączącej oba państwa, wzniesienie mostów na Amu-darii oraz współpracę w dziedzinie energetyki. Władze zainicjowały wiele regionalnych przedsięwzięć multilateralnych, mających na celu wzrost efektywności gospodarowania wodą, poprawę sytuacji ekologicznej oraz walkę z terroryzmem motywowanym religijnie (Weitz, 2018, s. 41-45; Paderina, 2018).

Przełomowym wydarzeniem w regionie była zainicjowana przez Szawkata Mirzijojewa konferencja poświęcona sytuacji w Afganistanie, która odbyła się w Taszkiencie w dniach 26-27 marca 2018 roku. W sympozjum wzięli udział wysocy funkcjonariusze Organizacji Narodów Zjednoczonych, a także Najwyższa Przedstawiciel Unii Europejskiej do spraw Polityki Zagranicznej i Bezpieczeństwa oraz ministrowie spraw zagranicznych Afganistanu, Rosji, Iranu, Pakistanu, Kazachstanu, Kirgistanu, Tadżykistanu, a także zastępca sekretarza stanu USA (Sputnik.ru, 2018). Sukces konferencji stał się symbolem coraz aktywniejszej roli Uzbekistanu w regionalnych stosunkach międzynarodowych.

Od 2016 roku Taszkient bardziej aktywnie uczestniczy w inicjatywach Szanghajskiej Organizacji Współpracy - regionalnej organizacji bezpieczeństwa istniejącej od 2001 roku, stawiającej sobie za cel walkę z separatyzmem, ekstremizmem i terroryzmem. Podczas szczytu tej organizacji w Astanie w 2017 roku Szawkat Mirzijojew wystąpił z inicjatywą na rzecz intensyfikacji współpracy naukowej, technicznej, oraz dialogu religii, kultur i cywilizacji (Weitz, 2018, s. 48).

Istotnym aspektem nowej polityki zagranicznej wprowadzanej przez prezydenta było dążenie do poprawy stosunków z Rosją. Niechęć wobec Moskwy była elementem polityki zagranicznej realizowanej w czasach Karimowa 
(w latach 2001-2005 Uzbekistan wchodził w skład otwarcie antyrosyjskiego sojuszu GUUAM). Wyraźne zbliżenie z Federacją Rosyjską było możliwe między innymi za sprawą pełnego odrzucenia stosowanej przez otoczenie polityczne Karimowa retoryki kwestionującej wartość rozwoju Uzbekistanu w ramach Związku Radzieckiego. Rolę pośrednika, który sprzyjał zbliżeniu obu rządów i patrona rosyjsko-uzbeckiego pojednania odegrał Aliszer Usmanow, rosyjski miliarder pochodzenia uzbeckiego (Sattarov, 2017).

Momentem przełomowym w relacjach rosyjsko-uzbeckich była wizyta Władimira Putina w Taszkiencie w październiku 2018 roku. Rosyjski prezydent przybył do stolicy Uzbekistanu wraz z liczącą przeszło tysiąc osób delegacją, w której skład wchodzili przedsiębiorcy, dyplomaci, prawnicy i inżynierowie. Podczas szczytu podpisano 785 umów gospodarczych o łącznej wartości 27 mld USD, między innymi projekt budowy w Uzbekistanie elektrowni jądrowej o mocy 2,4 gigawatów, co odpowiada około $20 \%$ całkowitego zapotrzebowania energetycznego państwa. W rezultacie spotkania prezydentów Putina i Mirzijojewa przygotowany i podpisany został dokument zatytułowany Program współpracy gospodarczej między Rządem Federacji Rosyjskiej i Rzadem Republiki Uzbekistan na lata 2019-2024. Program ten, mający na celu określenie i realizację priorytetowych dziedzin współpracy oraz aktywizację kooperacji w dziedzinie wspólnych projektów, stał się podstawą rozwoju współpracy handlowo-gospodarczej Moskwy i Taszkientu. Podczas wizyty Siergieja Ławrowa w Taszkiencie w styczniu 2020 roku głównym tematem była możliwość wstąpienia Uzbekistanu do Euroazjatyckiej Unii Gospodarczej. Oba państwa powróciły też do współpracy wojskowej - w 2017 i 2019 roku odbyły się wspólne manewry sił zbrojnych Rosji i Uzbekistanu. Taszkient zakupił też rosyjskie samoloty SU-30 oraz helikoptery Mi-35M (Hedlund, 2019).

Dobrze rozwijają się stosunki uzbecko-chińskie. Choć Chińska Republika Ludowa dzierży palmę pierwszeństwa w dziedzinie bezpośrednich inwestycji zagranicznych w regionie, jej rola w Uzbekistanie była dotąd wyraźnie mniejsza, niż w pozostałych państwach Azji Centralnej. Od 2016 roku Taszkient i Pekin rozwijają współpracę w dziedzinie handlu zagranicznego i projektów infrastrukturalnych. Uzbekistan jest bardzo ważnym uczestnikiem zainicjowanego przez Chiny programu Jeden Pas - Jedna Droga (OBOR), określanego niekiedy mianem Nowego Szlaku Jedwabnego. Kluczowym elementem 
tego transkontynentalnego projektu infrastrukturalnego jest korytarz transportowy (obejmujący drogi i linie kolejowe) wiodący z Chin przez Kirgistan, Uzbekistan, Turkmenistan i Iran do Turcji. Symbolem chińskich inwestycji w Uzbekistanie stał się tunel kolejowy Kamchiq w górach Qurama o długości 19,2 km, łączący Taszkient z Kotliną Fergańską. W maju 2017 roku, podczas wizyty Szawkata Mirzijojewa w Pekinie uzgodniony został program inwestycji Chińskiej Republiki Ludowej w Uzbekistanie o wartości 23 mld USD. W październiku 2018 roku premierzy obu państw Abdulla Aripow i Li Keqiang podpisali pakiet umów o partnerstwie w dziedzinie przemysłu, energii i transportu (Hedlund, 2019).

Innym ważnym partnerem zagranicznym jest Turcja - państwo, które jako pierwsze w 1991 roku uznało niepodległość Uzbekistanu. Czynnikiem zbliżającym oba państwa jest bliskość kulturowa i etniczno-językowa. Szawkat Mirzijojew odwiedził Ankarę w dniach 19-20 lutego 2020 roku. Jego spotkanie z prezydentem Recepem Erdoganem przebiegło w przyjaznej atmosferze. Choć skala inwestycji bezpośrednich Republiki Turcji w Uzbekistanie zdecydowanie ustępuje rosyjskiej i chińskiej, oba państwa dążą do intensyfikacji współpracy politycznej, gospodarczej i handlowej (Republic of Turkey. Ministry of Foreign Affairs).

Znaczącym partnerem Uzbekistanu spoza regionu staje się stopniowo Korea Południowa. Oba państwa współpracują w sferze energetyki, bankowości i finansów, a także budowy dróg, przemysłu maszynowego, medycyny i edukacji. Intensyfikacji ulega kooperacja w dziedzinie innowacji w zarządzeniu oraz w sferze naukowo-technicznej. Koreańscy specjaliści są zatrudniani jako doradcy prominentnych uzbeckich decydentów (Paderina, 2018).

Zachód także wydaje się wykazywać wzrost zainteresowania Uzbekistanem. Przez dłuższy czas Taszkient miał dobre relacje z Waszyngtonem (funkcjonowała nawet kluczowa baza lotnictwa amerykańskiego, wykorzystywana do transportu żołnierzy i sprzętu do Afganistanu), które jednak uległy drastycznemu pogorszeniu po wydarzeniach w Andiżanie w 2005 roku. Próbę odbudowania tych relacji Mirzijojew podjął w maju 2018 roku podczas spotkania z prezydentem Donaldem Trumpem w Waszyngtonie. W rezultacie podpisano 20 umów gospodarczych o łącznej wartości 4,8 mld USD - niewielkiej, biorąc pod uwagę ogromne oczekiwania oraz porównanie 
ze znacznie większą skalą inwestycji rosyjskich i chińskich. Co więcej, liczne uzbeckie przedsiębiorstwa współpracujące z partnerami rosyjskimi objętymi amerykańskimi sankcjami również podlegają reżimowi sankcyjnemu (co znacząco utrudnia amerykańską penetrację gospodarczą Uzbekistanu) (Hedlund, 2019). Trudno na razie powiedzieć, czy i w jaki sposób objęcie władzy przez Joe Bidena zmieni relacje amerykańsko-uzbeckie.

Polityka zagraniczna Uzbekistanu w okresie prezydentury Szawkata Mirzijojewa staje się coraz bardziej aktywna i ambitna. Warto odnotować jej wielowektorowy charakter - wyraźną poprawę relacji z innymi państwami Azji Centralnej, obopólnie korzystne partnerstwo z Rosją i Chinami, a także wzmacnianie więzi z partnerami spoza regionu. Dzięki coraz bardziej efektywnej polityce zagranicznej i implementacji strategii otwarcia na świat Uzbekistan po przeszło dwóch dekadach polityki izolacjonizmu stopniowo staje się regionalnym liderem.

\section{Uwagi końcowe}

Choć niektórzy obserwatorzy wykazują sceptycyzm co do reform społeczno-politycznych w Uzbekistanie, znacznie więcej argumentów przemawia za tezą, zgodnie z którą Szawkat Mirzijojew zapoczątkował głęboką transformację państwa. Wprawdzie niektóre aspekty jego polityki (jak na przykład neoliberalny program gospodarczy) mogą budzić kontrowersje, to jednak model władzy politycznej i życia społecznego uległ znaczącej zmianie. Odejście od zachowawczego, restrykcyjnego i izolacjonistycznego kursu Karimowa wydaje się konsekwentne i nieodwracalne.

Przez dwa ostatnie stulecia Uzbekistan nie był podmiotem relacji międzynarodowych, lecz raczej przedmiotem rywalizacji wielkich światowych potęg, a następnie częścią składową potężnego imperium. Obecnie państwo to dynamicznie się rozwija i stopniowo staje się znaczącym regionalnym aktorem geopolitycznym. Choć wielkie mocarstwa nadal są zainteresowane włączeniem Uzbekistanu w sferę swoich wpływów, to rosnący potencjał państwa oraz umiejętnie prowadzona wielowektorowa polityka zagraniczna tworzą szanse na uzyskanie rzeczywistej niezależności i podmiotowości. Dopiero z perspektywy następnych dziesięcioleci będzie można ocenić, na ile istotną rolę $\mathrm{w}$ tym procesie odegra głęboki, wieloaspektowy program 
reformatorski, zainicjowany i wdrażany przez prezydenta Szawkata Mirzijojewa, obejmujący między innymi liberalizację systemu sprawowania władzy, przemiany gospodarcze i zmianę wektorów w polityce międzynarodowej. Niezależnie od tego, czy program ten zakończy się pełnym sukcesem, bez wątpienia stanie się istotnym punktem odniesienia w wielowiekowej, pasjonującej historii Uzbekistanu.

\section{DR PRZEMYSŁAW SIERADZAN}

Zakład Kultury i Języków Azji Wschodniej

Wydział Filologiczny

Uniwersytet Gdański

ul. Wita Stwosza 55, 80-308 Gdańsk

przemyslaw.sieradzan@ug.edu.pl

\section{Bibliografia}

Akmal' Saidov: Rešenie parlamenta sootvetstvuet zakonam (2016,11 września). KUN.UZ. Pobrane z: https://kun.uz/ru/news/2016/09/11/akmal-saidov-resenie-parlamenta -sootvetstvuet-zakonam.

Bazyleva, S.P. (2017). Elitnaâ bor'ba i stabil'nost' političeskogo režima v Uzbekistane. Vestnik RUDN, 19(1), 77-82.

Bodio, T. (2001). Daleki-bliski Uzbekistan. W: T. Bodio (red.), Uzbekistan. Historia społeczeństwo - polityka. Warszawa: Elipsa.

Bodio, T. (2007). Paradoksy polityki posttotalitarnej (na przykładzie Azji Centralnej).W: M. Karwat (red.), Paradoksy polityki. Warszawa: Dom Wydawniczy Elipsa.

Bodio, T. (2001). Polska-Uzbekistan: współpraca gospodarcza. W: T. Bodio (red), Uzbekistan. Historia - społeczeństwo - polityka. Warszawa: Elipsa.

Bodio, T. (2020). Uzbekistan - państwo w totalnej przebudowie. Nowa Polityka Wschodnia, 2(25), s. 90.

Džanašiâ, V. (2018, 25 sierpnia). Uzbekskaâ ottepel'. Expert.ru. Pobrane z: https://expert. ru/expert/2018/13/uzbekskaya-ottepel/.

Fazendeiro, B. (2017). Uzbekistan's Foreign Policy. The Struggle for Recognition and Self-Reliance under Karimov. Milton Park/New York: Routledge.

Fedŭk, R. (2016, 2 września). 8 klanov v Uzbekistane: kto pretenduet na tron Karimowa? DEPOUA. Pobrano z: https://www.depo.ua/rus/svit/chi-chekae-na-uzbekistan-viyna-klaniv-30082016140000.

Hedlund, S. (2019, 15 lutego). Uzbekistan emerging from isolation. Geopolitical Intelligence Service. Pobrane 
z: https://www.gisreportsonline.com/uzbekistan-emerging-from-isolation,politics,2801.html.

Hodžaev, B. (2019, 29 sierpnia). Na vysokoj skorosti. Rossijskâ gazeta. Pobrane z: https:// rg.ru/2019/08/29/ekonomicheskie-i-socialnye-reformy-v-uzbekistane-nabrali-oboroty.html.

Hopkirk, P. (2011). Wielka Gra. Sekretna wojna o Azję Środkową (przeł. J. Skowroński). Poznań: Zysk i S-ka.

International Monetary Fund (2020). IMF Country Report. Republic of Uzbekistan. No. 20/171.

Biografiâ. Islomkarimov.uz a. Pobrane z: http://islomkarimov.uz/ru/page/tarjimai-hol. Naučno-prosvetitel'skij kompleks Islama Karimova. Islomkarimov.uz b. Pobrane z: www.islomkarimov.uz.

Karimow, I. (2001). Uzbekistan na progu XXI wieku (przeł. D. Muszyńska-Wolny). Warszawa: Dom Wydawniczy „Elipsa”.

Konferenciâ po Afganistanu v Taškente (2018, 26 marca). Sputnik.ru. Pobrane z: https:// uz.sputniknews.ru/infographics/20180326/7811883/konferenciya-po-afganistanu -v-tashkente.html?_ga=2.43921389.970737602.1602707034-708053416 1602707034 .

Leontev, M. (2008). Bol’šâ̂ igra: britanskaâ imperiâ protiv Rossii i SSSR. Moskva-Sankt Peterburg: Izdatel'stvo Astrel'.

Mirzieev vpervye v svyazi so svâščennym Ramzan Hajitom pomiloval 226 graždan (2018, 13 czerwca). Muslim.uz. Pobrane z: http://muslim.uz/index.php/rus/novosti-2018/ item/8876-mirzijoev-vpervye-v-svyazi-so-svyashchennym-ramazan-khajitom-pomiloval-226-grazhdan.

Marszewski, M. (2018). Odwilż w Uzbekistanie. Reformy prezydenta Mirzijojewa. Komentarze OSW, 278.

Mirzoân, G. (2016, 1 września). Posle Karimova. Expert.ru. Pobrano z: http://expert. ru/2016/09/1/poslekarimova.

Paderina, S. (2018, 1 lutego). Uzbekskij Den Siaopin: novaâ vnešnââ politika Šavkata Mirzieeva, Russkij sovet po mezdunarodnym delam. Russian Council. Pobrane z: https://russiancouncil.ru/blogs/sofia-paderina/33998/.

Pannier, B. (2016, 29 sierpnia). Who Could Replace Uzbekistan's Ailing President. Radio Free Europe-Radio Liberty. Pobrane z: https://www.rferl.org/a/who-would-replace-uzbekistan-karimov-president/27952766.html.

Relations between Turkey and Uzbekistan. Republic of Turkey. Ministry of Foreign Affairs. Pobrane z: http://www.mfa.gov.tr/relations-between-turkey-and uzbekistan\%20.en.mfa\#: :text=Turkey\%20became $\% 20$ the $\% 20$ first $\% 20$ country,countries\%20on\%204\%20March\%201992.\&text=Our\%20trade\%20volume\%20with\%20 Uzbekistan,with\%20Turkish\%20capital\%20in\%20Uzbekistan.

Sattarov, R. (2017, 16 listopada). Alisher Usmanov: Uzbekistan's Oligarch of Choice, Carnegie Moscow Center. Carnegie. Pobrane z: https://carnegie.ru/commentary/74756. Šavkat Mirzieev nazval prokurorov „samymi bol'šimi vorami” (2017, 4 sierpnia). Radio Ozodlik. Pobrane z: https://rus.ozodlik.org/a/28658153.html.

Spechler, M.C. (2008). The Political Economy of Reform in Central Asia. Uzbekistan under Authoritarianism. London/New York: Routledge. 
Starr, S.F. (2018). Continuity and Change in Uzbekistan, 1991-2016. W: S.F. Starr, S.E. Cornell (red.), Uzbekistan's New Face. Lanham-Boulder-New York-London: Rowman \& Littlefield.

Swerdlow, S. (2019, 1 września). Charting Progress in Mirziyoyev's Uzbekistan. The Diplomat. Pobrane z: https://thediplomat.com/2019/08/charting-progress -in-mirziyoyevs-uzbekistan/.

Tolibov, S. (2018, 22 lutego). Sročno: V Uzbekistane arestovan Rašid Kadyrov. Radio Odozlik. Pobrane z: https://rus.ozodlik.org/a/29057247.html.

Trofimov, Y. (2017, 14 sierpnia). In Uzbekistan, Signs of Thaw after the Decades of Repression. Wall Street Journal. Pobrane z: https://www.wsj.com/articles/ in-uzbekistan-signs-of-a-thaw-after-decades-of-repression-1505381404.

Uzbekistan. Central Intelligence Agency. Pobrane z: https://www.cia.gov/library/ publications/the-world-factbook/geos/uz.html.

Uzbekistan's new president closes Jaslyk prison camp. (2019, 8 sierpnia). The Economist. Pobrane z: https://www.economist.com/asia/2019/08/08/uzbekistans-newpresident-closes-jaslyk-prison-camp.

Virtualnaâ priemnaâ Prezidenta Respubliki Uzbekistan. pm.gov.uz/ru.

Vosem' glavnyh reform Šavkata Mirzieeva (2018, 19 lutego). Biznes Rossii. Pobrane z: https://glavportal.com/materials/vosem-glavnyh-reform-shavkata-mirziyoeva.

Vystuplenie Šavkata Mirzieeva na 72-j Genassamblee OON (2017, 20 września). Sputnik. ru. Pobrane z: http://ru.sputniknews-uz.com/video/20170920/6344700/Mirzieev-OON-vystuplenie.html.

Weitz, R. (2018). Uzbekistan's New Foreign Policy: Change and Continuity Under the New Leadership. W: S.F. Starr, S.E. Cornell (red.), Uzbekistan's New Face. Lanham-Boulder-New York-London: Rowman \& Littlefield.

Žegulev, I. (2018, 22 października). Eto ne ottepel', eto real'no vesna. V postsovetskoj strane umer diktator - i vse izmenilos', Meduza. Pobrane z: https://meduza.io/ feature/2018/10/22/eto-ne-ottepel-eto-realno-vesna. 